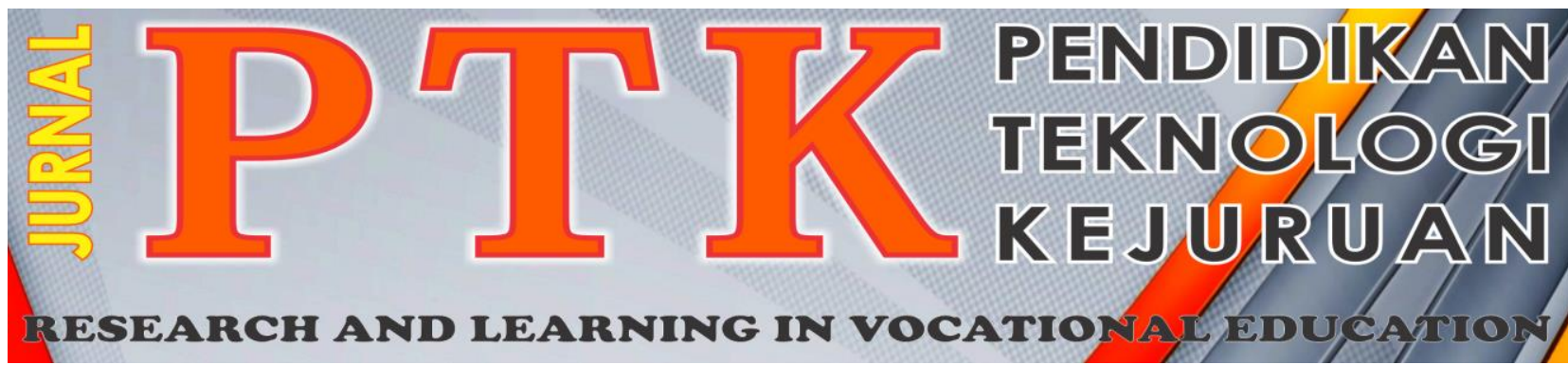

Vol. 2, No. 2, 2019

P-ISSN: 2621-3273

E-ISSN: 2621-1548

\title{
Pengembangan Media Pembelajaran Elektronik Berbasis Masalah pada Mata Pelajaran Komputer dan Jaringan Dasar
}

\author{
Eko Ady Saputra1, Wakhinuddin ${ }^{2}$, Fahmi Rizal $^{3}$ \\ ${ }_{1,2,3}$ Pascasarjana Pendidikan Teknologi dan Kejuruan \\ Universitas Negeri Padang, Padang 25132, Indonesia \\ *Corresponding author, e-mail: ekoadysaputra.132@gmail.com ${ }^{1}$
}

\begin{abstract}
Abstrak - Penelitian ini bertujuan untuk mendapatkan media pembelajaran elektronik berbasis masalah yang valid, praktis, dan efektif pada mata pelajaran komputer dan jaringan dasar. Media pembelajaran elektronik berbasis masalah ini dirancang untuk dapat meningkatkan pemahaman dan aktifitas siswa sehingga meningkatkan hasil belajar. Penelitian ini menggunakan metoda penelitian Research and Development $(R$ and D) dengan prosedur pengembangan 4-D (define, design, develop, dan disseminate). Teknik analisis data menggunakan teknik analisis deskriptif untuk mendeskripsikan validitas, praktikalitas, dan efektivitas media pembelajaran elektronik berbasis masalah. Hasil yang diperoleh dari penelitian pengembangan ini: (1) validitas media pembelajaran elektronik berbasis masalah dinyatakan valid pada aspek media dan aspek materi, (2) praktikalitas media pembelajaran elektronik berbasis masalah berdasarkan respon guru dan siswa dinyatakan sangat praktis, (3) efektivitas media pembelajaran elektronik berbasis masalah dinyatakan efektif dalam meningkatkan hasil belajar dan motivasi belajar. Berdasarkan temuan penelitian ini disimpulkan bahwa media pembelajaran elektronik berbasis masalah dinyatakan valid, praktis, dan efektif untuk dimanfaatkan sebagai bahan ajar pada mata pelajaran Komputer dan Jaringan Dasar.
\end{abstract}

\section{Kata kunci: Media Pembelajaran Elektronik, Penelitian dan Pengembangan}

\begin{abstract}
This study aims to obtain valid, practical, and effective problem-based electronic learning media on the computer and basic network subjects. Problem-based electronic learning media is designed to be able to improve student understanding and activities so as to improve learning outcomes. This research uses Research and Development ( $R$ and $D)$ research method with 4-D development procedures (define, design, develop, and disseminate). Data analysis techniques used descriptive analysis techniques to describe the validity, practicality, and effectiveness of problem-based electronic learning media. The results obtained from this development research: (1) the validity of problem-based electronic learning media is declared validly on media aspects and material aspects (2) the practicality of problem-based electronic learning media based on teacher and student responses is declared very practically (3) the effectiveness of learning media Problem-based electronics are declared effective in improving learning outcomes and learning motivation. Based on the findings of this study concluded that the problem-based electronic learning media is declared validly, practical and effective to be used as teaching materials in the Computer and Basic Network subjects.
\end{abstract}

Keywords: Electronic Learning Media, Research and Development

\section{Pendahuluan}

Kecanggihan media informasi yang mulai merambah ke seluruh lapisan masyarakat, yang terkena dampaknya dengan kondisi ini adalah peserta didik/siswa, karena mereka diharapkan nantinya mengerti sejauh mana perkembangan teknologi khususnya dalam dunia komputer.
Kecanggihan teknologi saat ini, belum dapat dipastikan telah dikuasai oleh peserta didik/siswa. Akan tetapi, sebagian siswa tentunya telah mengenalinya. Kecanggihan teknologi ini akan sangat berkaitan dengan perkembangan pendidikan.

Pembelajaran adalah suatu proses interaksi yang terjadi antara pendidik dan peserta didik dalam suatu lingkungan belajar untuk mencapai tujuan belajar. 
Pembelajaran harus didukung dengan baik oleh semua unsur dalam pembelajaran yang meliputi guru, siswa dan juga lingkungan belajar. Pembelajaran yang dilihat pada penelitian ini adalah Pendidikan Kejuruan. Huges sebagaimana dikutip oleh Soeharto mengemukakan vocational education (pendidikan kejuruan) adalah pendidikan khusus yang program-programnya atau materi pelajarannya dipilih untuk siapapun yang tertarik untuk mempersiapkan diri bekerja sendiri, atau untuk bekerja sebagai bagian dari suatu grup kerja [1]. Pendidikan kejuruan menurut penjelasan UU No. 20 Tahun 2003 Pasal 15. "Pendidikan kejuruan merupakan pendidikan menengah yang mempersiapkan peserta didik terutama untuk bekerja dalam bidang tertentu". Pendidikan kejuruan terdiri dari Sekolah Menengah Kejuruan (SMK) dan Madrasah Aliyah Kejuruan (MAK).

Sejalan dengan pernyataan di atas, Sekolah Menengah Kejuruan (SMK) pada saat ini menerapkan kurikulum 2013. UU No. 20 Tahun 2003 Pasal 1 (19) tentang Sistem Pendidikan Nasional menyebutkan bahwa "Kurikulum adalah seperangkat rencana dan pengaturan mengenai tujuan, isi, dan bahan pelajaran serta cara yang digunakan sebagai pedoman penyelenggaraan kegiatan pembelajaran untuk mencapai tujuan pendidikan tertentu". Kurikulum 2013 menuntut pembelajaran yang berpusat kepada siswa, dan siswa dalam hal ini dituntut untuk aktif dalam pembelajaran dikelas maupun diluar kelas, pembelajaran diluar kelas dapat berupa pembelajaran menggunakan media elektronik secara online yang dapat diakses melalui internet. Dalam kurikulum 2013 guru berperan sebagai fasilitator, hal ini membuat guru perlu menyiapkan media pembelajaran yang dapat membantu dalam peroses belajar mengajar dan untuk memberi ruang kepada siswa agar bisa belajar secara mandiri sesuai dengan kemampuan dan ketertarikan siswa tersebut. Salah satu sarana utama dalam mendukung proses media pembelajaran e-learning dapat dengan memanfaatkan LMS (Learning Menajemen System) terdapat berbagai LMS yang bersifat open source yang dapat digunakan, yaitu Moodle, Atutor, Wordpress, e-Front dan Dokeos. Salah satu mata pelajaran yang membutuhkan media dalam melaksanakan proses pembelajaran yaitu, mata pelajaran Komputer dan Jaringan Dasar.

Komputer dan Jaringan Dasar merupakan mata pelajaran wajib dasar bidang keahlian Teknik Komputer dan Informatika (TKI) yang harus dijalani oleh siswa, Berdasarkan struktur kurikulum mata pelajaran Komputer dan Jaringan Dasar disampaikan di kelas $X$ semester 1 dan semester 2 masing-masing 3 jam pelajaran, salah satu kompetensi dasar yang akan dipelajari yaitu, kesehatan keselamatan kerja dan lingkungan hidup (K3LH), perakitan komputer, pengujian perakitan komputer, konfigurasi BIOS, instalasi sistem operasi, instalasi driver, instalasi software aplikasi, perawatan perangkat keras komputer, jaringan dasar komputer dan troubleshooting komputer. Pada kompetensi dasar ini terdapat materi teori dan praktik yang perlu dikuasai oleh siswa, sehingga kompetensi ini membutuhkan model dan media yang dapat membantu siswa dalam memahami pembelajaran.

Permasalahan yang dialami selama proses pembelajaran Komputer dan Jaringan Dasar seperti motivasi dan keaktifan siswa dalam proses pembelajaran masih kurang, kompetensi dasar yang harus dicapai siswa cukup padatnamun waktu yang tersedia untuk tatap muka dikelas itu terbatas [2]. Dalam menyampaikan materi pelajaran guru hanya menampilkan slide presentasi, selain itu materi yang tergolong sulit dipahami oleh peserta didik membuat proses pembelajaran menjadi kurang aktif karena hanya guru sebagai sumber materi dan peserta didik hanya mendengarkan dan keterbatasan waktu juga menjadi hambatan guru dalam menyampaikan materi pembelajaran di kelas sehingga guru kekurangan waktu dalam mengontrol pembelajaran [3].

Belum tersedianya buku, modul atau lembar kerja siswa untuk mata pelajaran produktif pada kurikulum baru ini membuat guru harus lebih berpikir bagaimana memberikan suatu media yang dapat membantu siswa dalam proses belajar tanpa harus bergantung pada guru, waktu dan tempat seiring dengan perkembangan teknologi yang semakin pesat [4][5]. Media pembelajaran sekolah yaitu media power point, bahan ajar yang di download dari internet dan motivasi siswa masih kurang karena sumber belajar masih berpedoman pada materi yang diberikan guru saja[6].

Hal ini sejalan dengan observasi yang dilakukan di SMK Muhammadiyah 1 Padang, pada jurusan Teknik Komputer dan Jaringan (TKJ) SMK Muhammadiyah 1 Padang pada mata pelajaran Komputer dan Jaringan Dasar kelas X, proses pembelajaran Komputer dan Jaringan Dasar yang ada belum maksimal, masih terdapat adanya kendala dalam pembelajaran seperti, kurangnya inovasi dalam melakukan pengembangan media pembelajaran yang digunakan, hal ini terlihat dari penggunaan media pembelajaran oleh guru mata pelajaran hanya menggunakan media power point yang masih belum dikembangkan.

Selain itu siswa kurang aktif dalam melaksanakan pembelajaran sehingga proses pembelajaran bersifat monoton dan perlu adanya media pembelajaran yang dapat membantu siswa 
dalam melaksanakan pembelajaran di kelas maupun di luar kelas, baik itu secara mandiri ataupun berkelompok, maka dari itu dibutuhkan media pembelajaran yang dapat menutupi kekurangan yang ada. Mata pelajaran Komputer dan Jaringan Dasar ini bersifat teori dan praktik yang membutuhkan media untuk membantu siswa dan guru dalam melaksanakan pembelajaran, dengan banyaknya teori dan praktik bersifat abstrak yang membuat siswa kesulitan dalam memahami materi dan membutuhkan banyak waktu untuk menjelaskan materi secara detail.

Hal ini mengakibatkan siswa kurang maksimal dalam melaksanakan proses pembelajaran yang ada. Sedangkan dengan semakin besar partisipasi siswa dalam pembelajaran akan dapat meningkatkan daya ingat dan pemahamaan siswa. Selain itu pembelajaran hanya dapat dilakukan di dalam kelas yang menyebabkan kurang maksimalnya pembelajaran apabila pertemuan tidak terjadi, hal seperti ini dapat menghambat proses berlangsungnya pembelajaran yang ada.

Selain itu faktor lain yang menjadi penyebab kurang maksimalnya proses pembelajaran adalah keterbatasan waktu, karena proses pembelajaran hanya mengandalkan pembelajaran tatap muka di dalam kelas sedangkan jam pembelajaran terbatas, sehingga tidak semua materi dapat disampaikan secara maksimal. Kondisi seperti ini berdampak terhadap hasil belajar siswa masih tergolong rendah, rendahnya hasil belajar siswa ini merupakan dampak dari permasalahan yang ada. Persentase ketuntasan siswa kelas X TKJ pada mata pelajaran Komputer dan Jaringan Dasar tahun pelajaran 2017/2018 masih terdapat siswa yang belum mencapai Keriteria Ketuntasan Minimum (KKM), seperti yang ditunjukan pada Tabel 1.1.

Tabel 1 Persentase Nilai Ujian Tengah Semester Ganjil Komputer dan Jaringan Dasar Kelas X TKJ

SMK Muhammadiyah 1 Padang Tahun Ajaran $2017 / 2018$

\begin{tabular}{lccccll}
\hline & & Jumlah & \multicolumn{2}{c}{$\begin{array}{c}\text { Nilai }<75 \\
(\text { KKM })\end{array}$} & \multicolumn{2}{l}{$\begin{array}{l}\text { Nilai } \geq 75 \\
(\text { KKM })\end{array}$} \\
\cline { 3 - 7 } No & Kelas & Siswa & Jumlah & $\%$ & Jumlah & $\%$ \\
\hline 1 & XKJ & 30 & 21 & $70,00 \%$ & 9 & $30,00 \%$ \\
\hline
\end{tabular}

Sumber: Guru Komputer dan Jaringan Dasar Kelas $X T K J$

Berdasarkan Tabel 1 dapat diketahui masih terdapat beberapa siswa yang belum mencapai KKM yaitu terdapat 21 orang siswa yang belum mencapai KKM. Faktor yang diduga menjadi masalah utama yang mempengaruhi hasil belajar siswa adalah kurangnya perhatian dan keaktifan siswa terhadap materi yang disampaikan oleh guru. Adapun solusisolusi yang ditawarkan oleh peneliti sebelumnya untuk mengatasi permasalahan-permasalahan tersebut yaitu, pengimplementasian media pembelajaran berupa e-modul atau elektronik modul, e-modul memiliki kelebihan dibandingkan dengan modul cetak yaitu dari sifatnya yang interaktif memudahkan dalam navigasi, memungkinkan menampilkan/memuat gambar, audio, video dan animasi serta dilengkapi tes/kuis formatif yang memungkinkan umpan balik otomatis dengan segera dan sala satu pembelajaran yang dapat meningkatkan keaktifan siswa adalah model pembelajaran problem based learning [2]. Dengan menggunakan modul elektronik diharapkan dapat meningkatkan minat belajar siswa yang rendah, hal ini dikarenakan materi dalam e-modul dapat dikemas lebih menarik (penambahan animasi, video dan audio) serta modul dirancang agar siswa mampu belajar mandiri [6].

Menurut Nelly menyatakan e-learning efektif dalam meningkakan hasil belajar siswa [7] dan menurut Numiek menyatakan pelaksanaan pembelajaran e-learning sebagai media pembelajaran cukup efektif [8]. Melihat dari penelitian pengembangan dan solusi yang dilakukan peneliti sebelumnya, penulis cukup yakin dengan mengambil judul pengembagan media pembelajaran elektronik berbasis masalah ini. Pembelajaran berbasis masalah (Problem Based Learning) menurut Rusman adalah menggunakan permasalah dunia nyata sebagai suatu kondisi bagi peserta didik supaya belajar tentang keterampilan pemecahan masalah dan berpikir secara kritis serta untuk memperoleh pengetahuan dan konsep yang nyata dari materi pelajaran [9].

Penggunaan media pembelajaran elektronik berbasis masalah ini diharapkan dapat mempengaruhi dalam proses pembelajaran yang awalnya siswa pasif menjadi lebih aktif. Pengunaan media pembelajaran elektronik berbasis masalah ini penyampaikan materi dari guru kepada siswa akan lebih mudah, media pembelajaran ini dapat membuat materi yang bersifat abstrak menjadi lebih konkrit, memberikan penugasan yang membuat siswa lebih memahami pembelajaran yang berlangsung di kelas maupun yang dilakukan di luar kelas, media pembelajaran ini bersifat interaktif yang dapat membantu meningkatkan aktifitas siswa, dalam media pembelajaran ini terdapat lembar kerja siswa, latihan soal, forum diskusi, materi dan video pembelajaran, dalam media pembelajaran ini siswa juga diarahkan untuk melaksanakan proses pembelajaran berbasis masalah yang nantinya akan diarahkan oleh guru mata pelajaran. Media pembelajaran elektronik berbasis masalah ini memanfaatkan perangkat ICT (Information and Communication Technology) dalam proses 
pembelajaran, karena media ini dapat diakses secara online, siswa dapat mengakses informasi mengenai materi pembelajaran yang diberkan oleh guru dimanapun dan kapanpun dengan adanya koneksi internet.

\section{METODE}

Model penelitian yang digunakan adalah penelitian pengembangan (Research and Development). Penelitian pengembangan adalah penelitian yang digunakan untuk menghasilkan produk tertentu dan menguji keefektifan produk tersebut [10]. Penelitian yang dilakukan dapat menciptakan produk tertentu, dilakuknnya penelitian yang bersifat analisis tentang kebutuhan dan dilakukannya uji keefektifan agar dapat digunakan dalam kehidupan bermasyarakat, oleh karena itu perlu adanya penelitian yang berguna untuk menguji keefektifan produk [10]. Berdasarkan definisi yang ada, dapat diambil kesimpulan bahwa pengembangan merupakan serangkaian kegiatan atau proses yang menghasilkan produk tertentu yang didukung oleh ilmu pengetahuan.

Model pengembangan media pembelajaran elektronik berbasis masalah ini menggunakan model pengembangan 4-D (four-D). Model ini dipilih karena mempunyai prosedur yang sederhana, mempunyai prosedur yang sistematis, sesuai dengan langkah-langkah penelitian pengembangan yang peneliti lakukan, serta dalam pengembangannya melibatkan penilaian ahli sehingga sebelum di uji coba media yang dikembangkan telah dilakukan revisi berdasarkan penilaian, saran, dan masukan para ahli. Proses pengembangan yang terdiri dari 4 tahap yaitu: (1) define (pendefinisian); (2) design (perancangan); (3) develop (pengembangan); (4) disseminate (penyebaran) [11].

\section{HASIL DAN PEMBaHASAN}

Hasil penelitian yang telah dilakukan adalah sebuah media pembelajaran elektronik berbasis masalah yang valid, praktis dan efektif pada mata pelajaran Komputer dan Jaringan Dasar kelas X SMK. Hasil perancangan media pembelajaran elektronik berbasis masalah dapat dilihat pada gambar 1, gambar 2, gambar 3 dan gambar 4

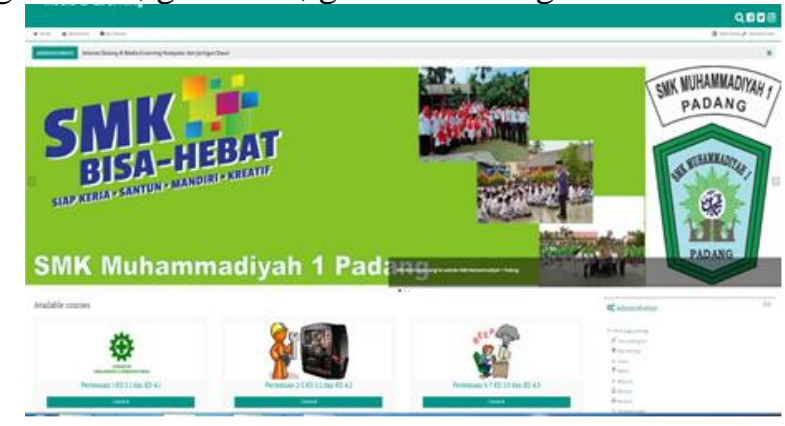

Gambar 1. Tampilan Awal Media Pembelajaran
Tampilan awal ini setiap siswa yang mau melaksanakan pembelajaran secara online harus login terlebih dahulu dengan memasukkan username dan password yang telah diberikan sebelumnya oleh guru mata pelajaran. Tampilan awal ini menampilkan seluruh jumlah pertemuan pelajaran sesuai silabus yang terdiri dari seluruh KD pada semester genap yang terdiri dari 18 pertemuan.

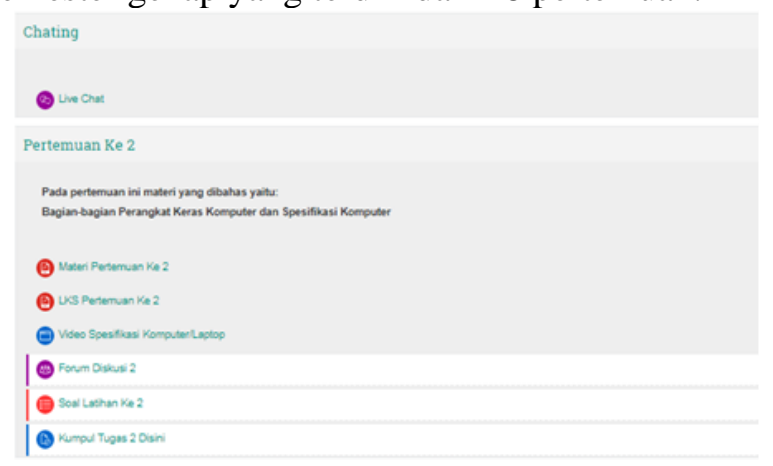

Gambar 2. Tampilan

Pada tampilan pelajaran ini merupakan daftar kontent-kontent yang tersedia pada media yang dapat diakses oleh guru ataupun siswa. Setiap kontent akan ada keterangannya sehingga siswa dapat memilih sesuai dengan runtutan materi yang ada.

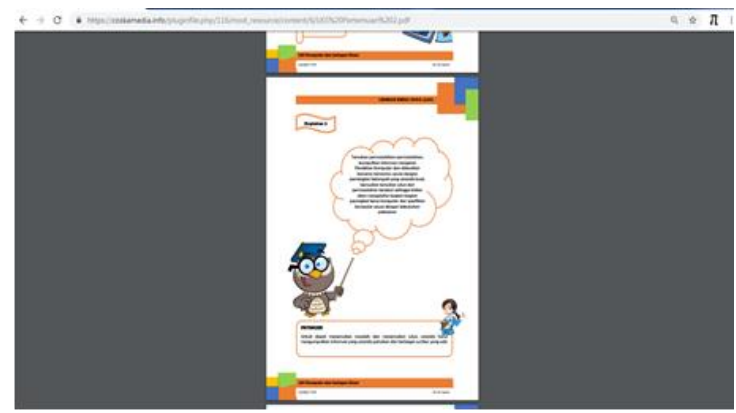

Gambar 3. Tampilan LKS

Tampilan LKS ini merupakan lembar kerja yang disiapkan oleh untuk mengarahkan siswa ke dalam pembelajaran berbasis masalah. LKS ini terdiri kompetensi dasar, indikator dan tujuan pembelajaran, petunjuk bagi siswa, orientasi pada masalah dan menemukan masalah yang terdiri dari narasi yang menstimulasi dan mengorientasi siswa kepada masalah dan menuliskan jawaban yang ditemukan, selanjutnya yaitu bagian untuk menentukan solusi dari permasalahan yang ditemukan oleh siswa, dan kolom kesimpulan untuk siswa menuliskan kesimpulan. 


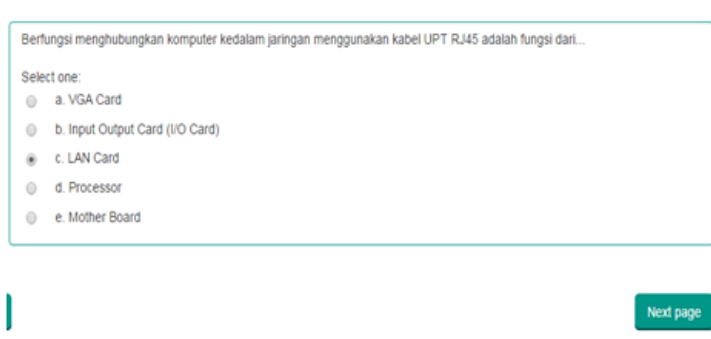

Gambar 4. Tampilan Latihan

Tampilan ini merupakan bentuk soal latihan yang berbentuk pilihan ganda. Soal ini dapat dikerjakan oleh siswa secara langsung dan siswa dapat mengetahui salah dan benarnya secara langsung ketika soal selesai dikerjakan. Setelah salah dan betulnya ditampilkan maka nilai hasil latihan siswa akan muncul secara langsung.

Media yang telah selesai dirancang diuji validitasnya. Validasi dilakukan oleh 3 orang pakar ahli media dan 3 orang pakar ahli materi. Aspek media yang divalidasi adalah aspek didaktik, kontruksi dan teknis. Aspek materi yang divalidasi adalah kualitas materi dan kualitas pembelajaran. Hasil yang didapat merupakan nilai validasi terhadap rancangan media pembelajaran, yang dirangkum sebagaimana terlihat pada Tabel 2 .

Tabel 2. Hasil Validasi Media Pembelajaran Elektronik Berbasis Masalah

\begin{tabular}{llcc} 
No & Validator & $\begin{array}{c}\text { Koefisien } \\
\text { Aiken's V }\end{array}$ & Klasifikasi \\
\hline 1 & Ahli Media & 0,87 & Valid \\
2 & Ahli Materi & 0,85 & Valid
\end{tabular}

Hasil analisis uji validitas kepada ahli media diperoleh rata-rata aspek sebesar $0,87 \geq 0,66$, hasil validasi dengan ahli materi diperoleh rata-rata sebesar $0,85 \geq 0,66$. Jadi, media pembelajaran elektronik berbasis masalah dinyatakan valid dari ahli media dan ahli materi.

Media telah dinyatakan valid selanjutnya dilakukan uji praktikalitas kepada guru dan siswa untuk mengetahui performa, dan kendala yang terjadi saat penggunaan media. Hasil yang diperoleh dirangkum sebagaimana terlihat pada tabel 3 .

Tabel 3. Hasil Respon Guru dan Siswa

\begin{tabular}{llc}
\hline No & Responden & Tingkat Pencapaian $(\%)$ \\
\hline $1 \quad$ Guru & 95,11 \\
$2 \quad$ Siswa & 84,24 \\
Rata-Rata & 89,67 \\
Kategori Aspek & Sangat Praktis
\end{tabular}

Hasil analisis respon guru dan respon siswa berdasarkan tabel 3 diperoleh rata-rata $89,67 \%$ dengan kategori sangat praktis berdasarkan. Jadi dapat disimpulkan bahwa media pembelajaran elektronik berbasis masalah dinyatakan praktis.
Media pembelajaran elektronik berbasis masalah yang sudah dinyatakan praktis, selanjutnya diujicobakan pada 32 siswa kelas $X$ SMK Muhammadiyah 1 Padang. Efektivitas media pembelajaran elektronik berbasis masalah dilihat dari tes hasil belajar.

Hasil analisis efektivitas media pembelajaran dilihat dari ketuntasan klasikal didapatkan 87,50\% siswa dinyatakan tuntas, dimana sebanyak 28 siswa mendapatkan nilai diatas Kriteria Ketuntasan Minimum (KKM) yakni 75. Hasil efektivitas juga dilihat dari perbandingan pre-test dan post-test menggunakan gain score yang dapat dilihat pada Tabel 4.

Tabel 4. Nilai Gain Score

\begin{tabular}{|c|c|c|c|}
\hline $\mathrm{N}$ & $\begin{array}{c}\text { Nilai } \\
\text { Minimum }\end{array}$ & $\begin{array}{c}\text { Nilai } \\
\text { Maksimum }\end{array}$ & $\begin{array}{c}\text { Gein } \\
\text { Score }\end{array}$ \\
\hline 32 & $\begin{array}{l}0.20 \\
\text { Kate }\end{array}$ & 0.86 & $\begin{array}{c}0,53 \\
\text { Sedang }\end{array}$ \\
\hline
\end{tabular}

Hasil analisis data pre-test dan post-test dengan gain score diperoleh nilai gain score $0,53 \geq 0,3$ dengan kategori sedang. Berdasarkan ketuntasan klasikal dan nilai gain score dapat disimpulkan bahwa media pembelajaran elektronik berbasis masalah yang dikembangkan efektif untuk meningkatkan pemahaman materi bagi siswa.

Berdasarkan hasil analisis data penelitian yang telah dilakukan, diperoleh hasil validasi media dan materi telah baik dan dapat di uji cobakan dilapangan. Nana dan Ahmad bahwa media pembelajaran hendaknya memenuhi syarat mudah dilihat (visible), menarik (interesting), dan tepat (accurate), yakni media harusnya dapat dibaca dengan mudah, didesain dengan menarik sehingga dapat memotivasi siswa, dan media sesuai dengan karakteristik materi pembelajaran [12].

Hasil uji praktikalitas media pembelajaran melalui pengamatan langsung, respon guru dan siswa dinyatakan sangat praktis, sehingga disimpulkan bahwa media pembelajaran elektronik berbasis masalah praktis dalam penggunaan. Sesuai dengan pendapat Nana dan Ahmad bahwa media pembelajaran harus memiliki nilai kepraktisan dan kesederahanaan sehingga dapat digunakan dengan mudah [12].

Hasil efektivitas ditinjau dari perbandingan hasil belajar antara pre-test dan post-test, didapatkan perbandingan setelah menggunakan media pembelajaran interaktif berbasis android. Oleh sebab itu, media pembelajaran interaktif berbasis android efektif dilihat dari hasil belajar siswa. Sejalan dengan pendapat Wina bahwa media pembelajaran yang digunakan harus memperhatikan efektifitas 
dalam penggunaannya sehingga dapat memudahkan pencapaian tujuan pembelajaran [13].

\section{KESIMPULAN}

Menghasilkan sebuah produk media pembelajaran berupa e-learning untuk mata pelajaran Komputer dan Jaringan Dasar di SMK Muhammadiyah 1 Padang.

Media pembelajaran elektronik berbasis masalah yang dihasilkan dinyatakan oleh para ahli sebagai media yang valid sehingga dapat digunakan sebagai media pembelajaran. Media pembelajaran elektronik berbasis masalah yang dihasilkan juga dinyatakan sebagai media yang praktis yang direspon oleh guru dan siswa. Media Pembelajaran elektronik berbasis masalah yang dihasilkan juga efektif digunakan, yang dibuktikan dengan hasil post-test yang menunjukkan peningkatan hasil belajar.

\section{DAfTar Pustaka}

[1] Soeharto, Desain Instruksional sebuah Pendekatan Praktis untuk Pendidikan Teknologi dan Kejuruan. Jakarta: Departemen Pendidkan dan Kebudayaan, Direktorat Jenderal Pendidkan Tinggi, Proyek Pengembangan Lembaga Pendidikan Tenaga Kependidikan, 1988.

[2] Garjita and D. A. A. Sari, "Pengembangan EModul Pada Mata Pelajaran Sistem Operasi Dengan Model Pembelajaran Problem Based Learning (Studi Kasus: Siswa Kelas X TKJ SMK Negeri 3 Singaraja)," Kumpul. Artik. Mhs. Pendidik. Tek. Inform., vol. 6, no. 1, 2017.

[3] Paska and I. Edo, "Pengembangan E-Modul Pada Mata Pelajaran Sistem Komputer Dengan Model Pembelajaran Problem Based Learning Kelas XI Teknik Komputer Dan Jaringan Di Smk Negeri 3 Singaraja," J. Pendidik. Teknol. dan Kejuru., vol. 14, no. $1,2017$.

[4] D. S. Yuniarti, "Penggunaan Modul Berbasis Moodle pada Pembelajaran di SMK," Dinamika, vol. 5, no. 2, 2014.

[5] M. A. Zaus, R. E. Wulansari, S. Islami, and D. Pernanda, "Perancangan Media Pembelajaran Listrik Statis dan Dinamis Berbasis Android," INTECOMS J. Inf. Technol. Comput. Sci., vol. 1, no. 1, pp. 1-7, 2018.

[6] I. G. Sudarma, "Pengembangan E-Modul Dengan Model Problem Based Learning Mata Pelajaran Pemrograman Dasar Kelas XI Teknik Komputer Dan Jaringan Di SMK Negeri 3 Singaraja," Kumpul. Artik. Mhs. Pendidik. Tek. Inform., vol. 6, no. 1, 2017.

[7] N. Safitri, "Pengembangan Pembelajaran Berbasis E Learning dengan Aplikasi Moodle Berdasarkan Teori Konstruktivistik pada Materi Menganalisis Peluang Usaha Kelas XI SMK," J. TeknoPedagogi, vol. 5, no. 1, 2015.

[8] N. S. Hanum, "Keefektifan E-Learning sebagai Media Pembelajaran (Studi Evaluasi Model Pembelajaran E-Learning SMK Telkom Sandhy Putra Purwokerto," J. Pendidik. Vokasi, vol. 3, no. $1,2013$.

[9] Rusman, Model - Model Pembelajaran. Depok: PT Rajagrafindo Persada, 2012.

[10] Sugiyono, Statistika untuk Penelitian. Bandung: CV. Alfabeta, 2014.

[11] Trianto, Mendesain Model Pembelajaran Inovatif-Progresif. Surabaya: Kencana Prenada Media Group, 2009.

[12] N. Sujana and A. Rivai, Media Pengajaran. Bandung: Sinar Baru Algesindo, 2015.

[13] W. Sanjaya, Strategi Pembelajaran Berorientasi Standar Proses Pendidikan. Jakarta: Kencana, 2009.

\section{Biodata Penulis}

Eko Ady Saputra, dilahirkan di Rimbo Bujang, 06 Agustus 1994. Menyelesaikan S1 pada jurusan Pendidikan Teknik Informatika dan Komputer UPIYPTK Padang tahun 2016 dan pendidikan Pascasarjana (S2) Magister Pendidikan Teknik bidang Pendidikan Teknologi dan Kejuruan pada tahun 2016. 